\title{
Habitual Coffee Consumption Increases Risks for Metabolic Diseases: Genome-wide Association Studies and a Phenotype-wide Two Sample Mendelian Randomization Analysis
}

Jiuling $\mathrm{Li}^{1}$, Tasnim Choudhury ${ }^{2}$, Miaoran Zhang ${ }^{1}$, Lanlan Chen ${ }^{3}$, Jianping Wen ${ }^{4}$, Wanqing Liu ${ }^{2,5, *}$, Peng Chen $^{1,4, *}$.

${ }^{1}$ Department of Pathology, College of Basic Medical Sciences, Jilin University. Changchun, Jilin 130021, China.

${ }^{2}$ Department of Pharmaceutical Sciences, Eugene Applebaum College of Pharmacy and Health Sciences, Wayne State University. Detroit, MI 48201, USA.

${ }^{3}$ The First Hospital of Jilin University, Jilin University. Changchun, Jilin 130021, China.

${ }^{4}$ Department of Genetics, College of Basic Medical Sciences, Jilin University. Changchun, Jilin 130021, China.

${ }^{5}$ Department of Pharmacology, School of Medicine, Wayne State University. Detroit, MI 48201, USA.

* These authors contributed equally to this work.

Correspondence: Wanqing Liu, PhD. Integrative Biosciences Center, Room 2401, Wayne State University, 6135 Woodward Ave, Detroit, MI 48202, USA. Tel: 1-313-577-3375; Email: wliu@wayne.edu.

Peng Chen, PhD. College of Basic Medical Sciences, Room 413, Jilin University, 126 Xinmin Street, Changchun, Jilin 130021, China. Email: pchen@jlu.edu.cn. 
medRxiv preprint doi: https://doi.org/10.1101/2021.03.08.21253114; this version posted March 9, 2021. The copyright holder for this preprint (which was not certified by peer review) is the author/funder, who has granted medRxiv a license to display the preprint in perpetuity.

It is made available under a CC-BY 4.0 International license .

\section{Abstract}

Background and aims: Coffee is one of the most widely consumed beverages in the world and has received considerable concerns regarding its impact on human health. Mendelian randomization (MR) could be valuable to explore the potential health effects of coffee via instrumental variables. In this study, we aim to identify novel genetic loci associated with habitual coffee consumption using genome-wide meta-analysis (GWMA) and to evaluate the broad impact of coffee consumption on human health and disease risk via a large-scale, phenotype-wide, two sample Mendelian randomization (TSMR) analysis.

Methods: We conducted a genome-wide association study (GWAS) among 283,926 coffee consumers of European ancestry in the UK Biobank (UKBB) to identify single nucleotide polymorphisms (SNPs) associated with the amount of coffee consumption (cups/day, GWAS 1), caffeine intake (GWAS 2) as well as the intake of non-caffeine substance in coffee (GWAS 3). The GWAS 1 results were further combined with the published results from the Coffee and Caffeine Genetics Consortium (CCGC) for a GWMA. TSMR were performed to evaluate the causal-relationship between coffee/caffeine/non-caffeine substance consumption and 1,101 diseases and health traits.

Results: The GWMA identified 50 lead SNPs among 19 genomic regions for habitual coffee consumption. Nine out of the 19 loci were novel, including ADAMTSL4-AS1, CACNA2D2, LINC02123-ADCY2, UBD-SNORD32B, SEMA4D-GADD45G, LOC101929457-LINGO1, RAI1, HCN2, and BRWD1. The GWAS 2 and 3 identified 2 (SORCS2 and SLC39A8) and 5 (LINC02060-LINC00461, AGR3-AHR, PRR4-TAS2R14, CYP1A1-CYP1A2, and FTO) genomic regions, respectively. TSMR analysis indicated that coffee consumption increased the risk of high blood lipids, obesity, and diabetes. Meanwhile, intake of caffeine and non-caffeine coffee components decreased and increased some of the blood lipids levels, respectively. 
medRxiv preprint doi: https://doi.org/10.1101/2021.03.08.21253114; this version posted March 9, 2021. The copyright holder for this preprint (which was not certified by peer review) is the author/funder, who has granted medRxiv a license to display the preprint in perpetuity.

It is made available under a CC-BY 4.0 International license.

Conclusions: Our study provided evidence that habitual coffee consumption could increase the risk of metabolic perturbations. The bioactive components in coffee, other than caffeine, may be more harmful to human health. Our findings have significant implications for global public health given the increasing burden of metabolic diseases.

Short title: coffee consumption genetics and health

Key words: Coffee consumption, Genome-wide association study, Mendelian randomization, single nucleotide polymorphism, caffeine, metabolic disease 
medRxiv preprint doi: https://doi.org/10.1101/2021.03.08.21253114; this version posted March 9, 2021. The copyright holder for this preprint (which was not certified by peer review) is the author/funder, who has granted medRxiv a license to display the preprint in perpetuity.

It is made available under a CC-BY 4.0 International license .

\section{Introduction}

Coffee is one of the most widely consumed beverages worldwide. The research community has been long debating whether coffee consumption is beneficial or harmful to health. Overall, observational studies favored the beneficial effect of coffee consumption in reducing the risk of metabolic syndrome, obesity, type 2 diabetes (T2D), cardiovascular disease, and several specific cancers ${ }^{1-4}$. However, evidence from randomized controlled trials (RCT) have shed light on the detrimental effects of coffee consumption, such as elevated blood lipids, blood glucose level, and fasting insulin level ${ }^{5-8}$.

The differences in the health outcomes of coffee consumption between the observational studies and RCT highlighted the necessity for further clarification. Mendelian randomization (MR) studies, which were considered to be advantageous to observational studies as they were similar to the RCT design but with comparable length of duration as those of the observational studies. They provided a potentially cost-effective strategy to examine the causal relationship between coffee consumption and health outcomes in human populations. A recent MR study found that coffee consumption increased the risk of osteoarthrosis and obesity ${ }^{9}$, while no significant effect on blood lipids or T2D was identified. Our recent MR analysis did not reveal a significant causal impact of coffee intake on nonalcoholic fatty liver disease (NAFLD) ${ }^{10}$. However, many of these MR studies on coffee consumption were limited in several aspects, with the limited power as a major issue, given the moderate effect of genetic alleles on coffee consumption habit. Therefore, the identification of more genetic susceptibility alleles underlying the coffee drinking habit among larger populations will increase the power for MR analysis. As such, the causal impact of coffee consumption on a broad range of health outcomes can be further elucidated.

In this study, we performed a genome-wide meta-analysis of coffee consumption among 375,388 individuals of European ancestry, which led to the identification of additional novel loci for habitual coffee consumption. Utilizing these expanded list of genetic risk alleles as instrument for coffee consumption, we further conducted two-sample MR (TSMR) analyses between coffee consumption and a large number of health outcomes previously studied among various GWAS. Furthermore, the GWASs 
medRxiv preprint doi: https://doi.org/10.1101/2021.03.08.21253114; this version posted March 9, 2021. The copyright holder for this preprint (which was not certified by peer review) is the author/funder, who has granted medRxiv a license to display the preprint in perpetuity.

It is made available under a CC-BY 4.0 International license .

of the consumption of caffeine and other coffee-containing, non-caffeine components were also conducted, respectively, and TSMR was also conducted. We observed a significantly detrimental causal impact of habitual coffee consumption and metabolic perturbations, which may be largely attributed to the non-caffeine components in coffee other than caffeine. 
medRxiv preprint doi: https://doi.org/10.1101/2021.03.08.21253114; this version posted March 9, 2021. The copyright holder for this preprint (which was not certified by peer review) is the author/funder, who has granted medRxiv a license to display the preprint in perpetuity.

It is made available under a CC-BY 4.0 International license .

\section{Methods}

\section{Study design and cohorts}

The study was conducted using the UK Biobank data resources under application number 53536. As shown in Figure 1, we conducted a GWAS of coffee consumption (GWAS 1) in the UK Biobank cohort (UKBB) and a genome-wide meta-analysis by combining the published results from the Coffee and Caffeine Genetics Consortium $(\mathrm{CCGC})^{11}$. The UKBB cohort included over 500,000 adult individuals recruited from the UK population between 2006 and 2010. The extensive phenotypic and genotypic data were collected among all participants ${ }^{12}$. The quality control on the genotype data followed the procedure recommended by the $\mathrm{UKBB}^{13}$. Our GWAS analysis was restricted to the coffee drinkers of European-ancestry. The participants who did not drink coffee were excluded. Finally, 283,926 participants were available for association testing. The genotypic data were further imputed based on the Haplotype Reference Consortium and the UK10K + 1000 genomes reference panel ${ }^{14}$. The CCGC study investigated two phenotypes, the quantitative coffee consumption (phenotype 1) and the comparison between high and low coffee consumers (phenotype 2). In the current study, phenotype 1, which included up to 91,462 coffee consumers of European ancestry, was used in the meta-analysis. This combination resulted in a total sample size of 375,388 . Functional annotation of GWAS summary was performed using FUMA GWAS ${ }^{15}$. To investigate the causal effect of coffee consumption, we employed a two-sample MR (TSMR) analysis to screen a broad spectrum of phenotypes in MR-Base ${ }^{16}$. After the enrichment analysis, the significant causal effects were further examined using a one-sample MR (OSMR) analysis using the phenotype defined in UKBB. To distinguish the effects of caffeine and other non-caffeine substances consumption on human health, we carried out the caffeine GWAS (GWAS 2) and other substances GWAS (GWAS 3) using the individual-level data of UKBB. The two phenotypes were defined as below. TSMR was also conducted after FUMA annotation.

\section{Phenotype definitions}

Our GWAS 1 was focused on the amount of daily coffee consumption (cups/day). In the UKBB data, coffee consumption (cups/day) and coffee type were surveyed at baseline using the touchscreen questionnaire. The amount of coffee consumption was determined by the question 'How many cups of 
medRxiv preprint doi: https://doi.org/10.1101/2021.03.08.21253114; this version posted March 9, 2021. The copyright holder for this preprint (which was not certified by peer review) is the author/funder, who has granted medRxiv a license to display the preprint in perpetuity.

It is made available under a CC-BY 4.0 International license .

coffee do you drink each day (include decaffeinated coffee)?'. If participants reported that they drink less than one cup of coffee per day, their cups per day were set as 0 . Participants with very high coffee consumption (> 8 cups/day) were excluded. Notably, the first phenotype of the CCGC study used in the subsequent meta-analysis study was also the number of cups of predominantly regular-type coffee consumed per day among coffee consumers ${ }^{11}$. Therefore, our new GWAS 1 is consistent with this previously conducted GWAS on coffee consumption. The coffee type was also coded and included as a covariate to be adjusted in the GWAS analysis. The coffee type was surveyed by the question "What type of coffee do you usually drink?" The options included decaffeinated coffee, instant coffee, ground coffee and others which were coded as $1,2,3$, and 4, respectively.

GWAS 2 aimed to identify genetic variants associated with caffeine consumption, in which 283,926 consumers with intake of any type of coffee were included. The consumers of decaffeinated coffee were then coded as category 0 , with the consumers of instant coffee, ground coffee, and other types of coffee coded as category 1. GWAS 3 aimed to identify genetic variants associated with other non-caffeine substances contained in coffee consumption, in which "non-coffee drinkers" were coded as 0 , with the drinkers consuming decaffeinated coffee as category 1.

\section{The genome-wide association study and meta-analysis}

To identify genetic variants associated with the daily amount of coffee consumption (cups/day), caffeine consumption, and non-caffeine substance consumption, three GWAS were performed using mixed linear model adjusted for age, sex, body mass index, smoking status (never, previous, current), and the first 5 genetic principal components. Coffee type was adjusted for coffee consumption GWAS in addition. The genetic principal components were calculated from the linkage disequilibrium (LD) pruned $\left(r^{2}<0.1\right)$ array genotype data of the participants of European ancestry. The autosomal SNPs with minor allele frequency $(\mathrm{MAF})>0.01$, imputation INFO score $>0.8$, missing rate $<0.05$, and HWE-Pval $>1 \times 10^{-6}$ were used in the genome-wide association study and meta-analysis. The meta-analysis was performed by combining the GWAS 1 results with that of the CCGC phenotype 1 (cups/day) GWAS using a fixed-effects inverse-variance weighted model $^{17}$. 
medRxiv preprint doi: https://doi.org/10.1101/2021.03.08.21253114; this version posted March 9, 2021. The copyright holder for this preprint (which was not certified by peer review) is the author/funder, who has granted medRxiv a license to display the preprint in perpetuity.

It is made available under a CC-BY 4.0 International license .

\section{Functional annotation of genome-wide association study and meta-analysis}

We used the web-based tool FUMA GWAS to define genomic risk loci and obtained functional information of relevant SNPs in these loci ${ }^{15}$. First, lead SNPs were defined using a genome-wide significant $\mathrm{P}$ value $\left(5 \times 10^{-8}\right)$ and $\mathrm{LD} \mathrm{r}^{2}<0.05$. All SNPs with significant $\mathrm{P}$ value $\left(5 \times 10^{-8}\right)$ in $\mathrm{LD}\left(\mathrm{r}^{2} \geq 0.05\right)$ with one of the lead SNPs were candidate SNPs. Further, genomic risk loci were identified by merging LD blocks if they were less than $250 \mathrm{~kb}$ apart.

Gene-mapping was based on two strategies. Firstly, positional mapping was performed by selecting exonic and splicing-site SNPs with CADD score $\geq 12.37^{18}$. Secondly, expression quantitative trait locus (eQTL) mapping was used to map SNPs to genes that show a significant eQTL association with these SNPs. The eQTL mapping was conducted using data generated in GTEx v8 ${ }^{19}$, and only cis-eQTLs (SNPs within $1 \mathrm{Mb}$ of a gene of interest) were included. The Benjamini-Hochberg false discovery rate $(\mathrm{FDR})^{20}$ of 0.05 was used to define significant eQTL associations. Gene enrichment and tissue specificity expression analysis were conducted using FUMA ${ }^{15}$ and TSEA

(http://genetics.wustl.edu/jdlab/tsea/), respectively. We used PhenoScanner to identify the pleiotropic effects of top lead $\mathrm{SNPs}^{21 ; 22}$.

\section{Mendelian randomization study}

The TSMR was performed in an inverse variance weighted (IVW) approach using lead SNPs associated with exposure as instrumental variables (IVs). For coffee consumption as the exposure, we used all 50 lead SNPs reaching the genome-wide level significance as IVs. For both caffeine and non-caffeine coffee intake as exposures, given the small number of SNPs reaching the genome-wide significance level, we used SNPs with a p value $<10^{-5}$ as IVs to reduce potential pleotropic effects. This results 38 and 83 IVs for caffeine and non-caffeine substance intake, respectively. For all candidate IVs, only when the p-value of the IVs in an outcome is at least greater than 0.001 , can it be used to infer the causality between the exposure and outcomes. The outcomes were the phenotypes available in MR-Base $(\mathrm{N}=1,101)$. MR-Egger regression and Cochran's Q test were used to detect the pleiotropic effect and the heterogeneity of the IVs. The causal effects estimated using the IVs with MR-egger intercept $p$ value 
medRxiv preprint doi: https://doi.org/10.1101/2021.03.08.21253114; this version posted March 9, 2021. The copyright holder for this preprint (which was not certified by peer review) is the author/funder, who has granted medRxiv a license to display the preprint in perpetuity.

It is made available under a CC-BY 4.0 International license.

$\leq 0.05$ or Cochran's Q p value $\leq 0.05$ were considered to be biased. The enrichment analysis of the significant causal effects (IVW $\mathrm{p} \leq 0.05$ ) in the categories defined by MR-Base was conducted using hypergeometric distribution test (https://systems.crump.ucla.edu/hypergeometric/index.php).

To reduce the false positive rate, the significant causal effects of coffee consumption (cups/day) on health outcomes were further validated using OSMR analysis using individual level UKBB data. In our OSMR study, the causal effect of coffee consumption on an outcome was estimated by the association between the coffee polygenic risk score (coffee-PRS) and the outcome. For each participant in the $\mathrm{UKBB}$, the coffee PRS was calculated by adding together the allele dosages of the instrumental variables, weighted by their association effects with coffee consumption. The association with a dichotomous or continuous outcome was estimated using a logistic regression or linear regression model, respectively, without an adjustment. For random blood glucose, the linear model was adjusted for the self-report fasting time.

\section{Statistical analysis}

The linear mixed model was estimated using the Genome-wide Complex Trait Analysis (GCTA) ${ }^{23}$. The genome-wide meta-analysis was performed using METAL ${ }^{17}$. The TSMR analysis was conducted using the TwoSampleMR package of $\mathrm{R}$ (version 0.4 .25 ). The polygenic risk score (PRS) and the explanation

of the coffee consumption by IVs $\left(\mathrm{R}^{2}\right)$ were evaluated by PRSice- $2^{24}$. The F-statistic was calculated by the following formula to estimate the statistical power of lead SNPs:

$$
F=\frac{N-K-1}{K} \times \frac{R^{2}}{1-R^{2}}
$$

$\mathrm{N}$ was the sample size, and $\mathrm{k}$ was the number of IVs.

Linear regression and logistic regression were conducted using $\mathrm{R}$ software (version 4.0.2, https://www.r-project.org/). 
medRxiv preprint doi: https://doi.org/10.1101/2021.03.08.21253114; this version posted March 9, 2021. The copyright holder for this preprint (which was not certified by peer review) is the author/funder, who has granted medRxiv a license to display the preprint in perpetuity.

It is made available under a CC-BY 4.0 International license .

\section{Results}

GWAS of coffee consumption (cups/day), caffeine consumption, and non-caffeine coffee consumption

Our GWAS 1 on coffee consumption involved 283,926 coffee consumers and 9,462,639 SNPs with MAF $>0.01$, imputation INFO score $>0.8$, and missing rate $<0.05$. The full details of the samples are provided in Supplementary Table 1. At this stage, we found 18 loci (Supplementary Table 2). After the meta-analysis by further combining the data of the CCGC GWAS, we were able to identify an additional significant locus (rs1571536, SEMA4D-GADD45G) (Figure 2A, Supplementary Table 3). Regional plots are available in the online resources (Supplementary Figure S1-2). Of the total of 19 identified loci, 6 loci including rs1260326 (GCKR), $\quad$ rs1481012 (ABCG2), $\quad$ rs4410790 (AGR3-AHR), $\quad$ rs799166 (MLXIPL-VPS37D), rs17685 (POR), and rs2472297 (CYP1A1-CYP1A2), were previously reported by CCGC $^{11}$. Four loci, rs2867110 (LOC105373352-TMEM18), rs476828 (PMAIP1-MC4R), rs56113850 (CYP2A6), and rs6512309 (PCMTD2), were identified by Zhong VW et al ${ }^{25}$. The 9 newly identified loci were rs6655975 (ADAMTSL4-AS1), rs1467913 (CACNA2D2), rs12519880(LINC02123-ADCY2), rs1235162(UBD-SNORD32B), $\quad$ rs1571536(SEMA4D-GADD45G), rs2667773 (LOC101929457-LINGO1), rs11078398 (RAI1), rs113534512 (HCN2), and rs3945 (BRWD1). Among which, rs6655975 (ADAMTSL4-AS1), rs1571536 (SEMA4D-GADD45G), rs2667773 (LOC101929457-LINGO1), and rs3945 (BRWD1) were nominally significant in the CCGC GWAS study at a significant level of 0.05 with the same direction for the associations (Table 1). For the locus 9 (MLXIPL-VPS37D), rs7800944 was identified as an index SNP in CCGC. In our results, the lead SNP rs799166 is in LD ( $\mathrm{r}^{2}=0.36$, among European Caucasian population) with rs7800944, and was predicted to be located in a SMAD2 binding site in JASPAR ${ }^{26}$. For the loci 13 and 17, the lead SNPs (rs2667773 and rs56113850) were not present in the CCGC GWAS findings. However, their LD proxy SNPs (rs2667768 and rs1496402) $\left(r^{2}>0.6\right.$ with the aforementioned lead SNPs among Caucasian population) were observed as the corresponding lead SNPs, respectively. Therefore, of the 50 lead SNPs, 35 were 
medRxiv preprint doi: https://doi.org/10.1101/2021.03.08.21253114; this version posted March 9, 2021. The copyright holder for this preprint (which was not certified by peer review) is the author/funder, who has granted medRxiv a license to display the preprint in perpetuity.

It is made available under a CC-BY 4.0 International license .

nominally validated in the previous CCGC study $(\mathrm{p}<0.05)$, while 15 were newly observed as lead SNPs only in the current meta-analysis (Supplementary Table 4).

The participants and SNPs used in the GWAS 2 were the same as the GWAS 1. At this stage, we found rs112764911 (SORCS2) and rs13107325 (SLC39A8) to be associated with caffeine consumption at the genome-wide level (Table 1, Figure 2B). Regional plots are available in the online resources (Supplementary Figure S3-4).

Our GWAS 3 of non-caffeine substances consumption involved 137,371 participants and 9,462,277 SNPs with MAF>0.01, imputation INFO score $>0.8$, and missing rate $<0.05$. We identified 5 lead SNPs associated with non-caffeine substances consumption, including rs2067919 (LINC02060), rs4410790 (AHR), rs1201669374 (PRR4), rs2472297 (CYP1A1), and rs11642015 (FTO) (Table 1, Figure 2C). Regional plots are available in the online resources (Supplementary Figure S5-6).

\section{Functional interpretation and pleiotropic effect of genetic variants}

We examined the potential causal variants within the identified SNPs $(n=2,597)$ associated with coffee consumption, SNPs $(n=14)$ associated with caffeine consumption, and SNPs $(n=268)$ associated with other non-caffeine substances consumption, we found that the majority of these SNPs are located in intergenic and intronic areas (Supplementary Figure S7-9). Ninety-five SNPs (Supplementary Table 5)

had likely deleterious impacts (CADD score $>12.37$ ) on gene functions ${ }^{18}$. Six nonsynonymous among 95 SNPs located at gene exon region, including rs79217743 (LMAN1L), rs2231142 (ABCG2), rs35332062 (MLXIPL), rs6720 (MDH2), rs113534512 (HCN2), and rs1057868 (POR).

We also examined whether the identified SNPs are also eQTLs for nearby genes. The results were included in Supplementary Table 6. We found that 1941, 4 and 219 SNPs that are associated with the three phenotypes of GWAS 1, 2 and 3 are also significant eQTLs (FDR<0.05) for 180 genes in at least one tissue, respectively. For example, rs56113850-C associated with coffee consumption, which is also 
medRxiv preprint doi: https://doi.org/10.1101/2021.03.08.21253114; this version posted March 9, 2021. The copyright holder for this preprint (which was not certified by peer review) is the author/funder, who has granted medRxiv a license to display the preprint in perpetuity.

It is made available under a CC-BY 4.0 International license.

significantly associated with increased expression of both CYP1A6 and CYP1A7 (Supplementary Table 7). Novel risk alleles for coffee consumption, rs6655975-A, rs1571536-C, rs2667773-A, and rs3945-G, are associated with increased expression of ADAMTSL4-AS1, GADD45G, LINGO1, and BRWD1, respectively (Supplementary Table 7). Rs12898397-C, a missense variant with deleterious impact $(\mathrm{CADD}$ score $=24.2)$ on $U L K 3$, is associated with increased coffee consumption while a decreased expression of ULK3 in multiple tissues (Supplementary Table 7). Rs11642015-T, associated with non-caffeine substances consumption, is associated with increased expression of FTO.

The gene enrichment analysis showed that these 180 GWAS SNP-associated genes were mainly involved in small molecule metabolic process, xenobiotic metabolic process, oxygenase p450 pathway, and generation of precursor metabolites and energy (Figure 3)._Enrichment for tissue-specific expression of these genes showed that they were significantly overrepresented in heart and liver (FDR <0.1) (Figure 4).

Some of the lead SNPs alleles associated with the amount of coffee consumption were also associated with other traits in previously published GWA studies (Supplementary Tables 8). For instance, the alleles of rs2867110-G and rs476828-C were associated with increased $\mathrm{BMI}^{27}$; rs1260326-C, rs3792253-C and rs799166-G were associated with lowered triglycerides ${ }^{28}$; rs1467913-C , rs351237-G , rs12902040-T , rs9783698-G , and rs12914012-T were associated with lowered height ${ }^{29 ; 30}$. In addition, several alleles associated with higher coffee consumption were associated with decreased impedance of body (e.g. rs11078398-G), lowered creatinine in the urine (e.g. rs2472297-T), and increased age at menarche (e.g. rs3945-G) ${ }^{30}$. The lead SNP rs13107325-C associated with increased caffeine consumption was also associated with decreased body mass index ${ }^{27}$. The lead SNPs rs2067919-C and rs11642015-T associated with increased non-caffeine substances consumption were also associated with decreased alcohol intake frequency and increased risk of diabetes, respectively ${ }^{30 ; 31}$. 
medRxiv preprint doi: https://doi.org/10.1101/2021.03.08.21253114; this version posted March 9, 2021. The copyright holder for this preprint (which was not certified by peer review) is the author/funder, who has granted medRxiv a license to display the preprint in perpetuity.

It is made available under a CC-BY 4.0 International license.

\section{Causal relationship between coffee consumption and the health consequences: TSMR}

We used the 50 lead SNPs provided by our meta-analysis (Supplementary Table 4) as the IVs in our TSMR analysis. TSMR analyses involved 1,101 phenotypes in MR-Base as outcomes. For each outcome, only when the p-value of the IVs in the outcome is at least greater than 0.001 , can it be used to infer the causality between coffee consumption and outcomes.

As shown in table 2, briefly we found significant causal relationships between coffee consumption and increased serum total cholesterol ( $\mathrm{id}=933$, beta $=0.133 \mathrm{SD}, \mathrm{p}=1.27 \times 10^{-3}, \mathrm{FDR}=1.86 \times 10^{-2}$ ), serum total triglycerides $\left(\mathrm{id}=934\right.$, beta $\left.=0.154 \mathrm{SD}, \mathrm{p}=3.75 \times 10^{-4}, \mathrm{FDR}=9.53 \times 10^{-3}\right)$, total cholesterol in $\mathrm{LDL}(\mathrm{id}=895$, beta $\left.=0.191 \mathrm{SD}, \mathrm{p}=4.49 \times 10^{-6}, \mathrm{FDR}=9.34 \times 10^{-4}\right)$, apolipoprotein $\mathrm{B}\left(\mathrm{id}=843\right.$, beta=0.233 SD, $\mathrm{p}=4.38 \times 10^{-8}$, $\left.\mathrm{FDR}=4.54 \times 10^{-5}\right)$, but decreased total cholesterol in HDL (id=864, beta=-0.128 SD, $\mathrm{p}=8.76 \times 10^{-4}$, $\left.\mathrm{FDR}=1.45 \times 10^{-2}\right)$. Furthermore, coffee consumption increased the risk of "less severe obesity", including overweight $\left(\mathrm{id}=93\right.$, beta $=0.124 \log$ odds, $\left.\mathrm{p}=8.87 \times 10^{-3}, \mathrm{FDR}=7.75 \times 10^{-2}\right)$ and obesity class $1(\mathrm{id}=90$, beta $=0.195 \log$ odds, $\mathrm{p}=4.45 \times 10^{-3}, \mathrm{FDR}=4.43 \times 10^{-2}$ ), but was not associated with obesity class 2 or 3 . At the same time, waist circumference $\left(\mathrm{id}=61\right.$, beta $=0.06 \mathrm{~cm}, \mathrm{p}=9.21 \times 10^{-4}, \mathrm{FDR}=1.45 \times 10^{-2}$ ), waist-to-hip ratio $\left(\mathrm{id}=74\right.$, beta $\left.=0.09 \mathrm{SD}, \mathrm{p}=2.1 \times 10^{-4}, \mathrm{FDR}>0.05\right)$, and body mass index $\left(\mathrm{id}=785\right.$, beta $=-0.08 \mathrm{~kg} / \mathrm{m}^{\wedge} 2$, $\mathrm{p}=7.19 \times 10^{-4}, \quad \mathrm{FDR}=1.29 \times 10^{-2}$ ) were also increased with coffee consumption. Besides, coffee consumption was shown to increase the risk of type 2 diabetes $\left(\mathrm{id}=25\right.$, beta $=1.15 \log$ odds, $\mathrm{p}=3.18 \times 10^{-3}$, FDR $=3.45 \times 10^{-2}$ ). In addition, the area under the curve (AUC) of insulin levels (id=760, AUCIns, beta $=-0.250 \mathrm{mU} * \min / \mathrm{L}, \mathrm{p}=2.48 \times 10^{-2}, \mathrm{FDR}>0.05$ ), and corrected insulin response (id=761, CIR, beta $\left.=-0.206 \mathrm{SD}, \mathrm{p}=3.21 \times 10^{-2}, \mathrm{FDR}>0.05\right)$ during an OGTT were all decreased by coffee consumption. Other traits observed in our TSMR analysis can be found in Supplementary Table 9. Notably, coffee consumption showed differential risk on two types of ovarian cancer, with an increased risk for endometrioid ovarian cancer $\left(\mathrm{id}=1125\right.$, beta $=0.349 \log$ odds, $\mathrm{p}=1.84 \times 10^{-3}, \mathrm{FDR}=2.37 \times 10^{-2}$ ) but a decreased risk of low grade and low malignant serous ovarian cancer (id=1229, beta=-0.331 log odds, $\left.\mathrm{p}=1.05 \times 10^{-2}, \mathrm{FDR}>0.05\right)$. 
medRxiv preprint doi: https://doi.org/10.1101/2021.03.08.21253114; this version posted March 9, 2021. The copyright holder for this preprint (which was not certified by peer review) is the author/funder, who has granted medRxiv a license to display the preprint in perpetuity.

It is made available under a CC-BY 4.0 International license .

To reveal the diseases categories or traits which are mostly affected by coffee consumption, we conducted an enrichment analysis of the significant causal effects. The results showed that the health outcomes causally driven by the coffee consumption were significantly enriched in several MR-base categories, i.e. blood lipids, fatty acids or amino acids in plasma/serum, and anthropometric measurements (Figure 5).

\section{Validation of the associations between coffee consumption and health outcomes: OSMR}

We used the IVs actually used in each outcome in the TSMR to construct the PRS score separately and inferred the relationship with the corresponding outcomes.

As shown in table 3, OSMR analyses were performed to further validate the significant findings in TSMR. In general, our results showed a consistent association between coffee consumption and similar metabolic traits as noted above. Briefly, the coffee-PRS was positively associated with cholesterol $\left(\mathrm{p}=1.65 \times 10^{-4}\right)$, LDL $\left(\mathrm{p}=7.76 \times 10^{-6}\right)$, apolipoprotein $\mathrm{B}\left(\mathrm{p}=1.24 \times 10^{-5}\right)$, but negatively associated with HDL $\left(6.56 \times 10^{-3}\right)$. Furthermore, coffee-PRS was positively associated with waist circumference $\left(\mathrm{p}=4.08 \times 10^{-10}\right)$, hip circumference $\left(\mathrm{p}=7.56 \times 10^{-9}\right)$, body mass index $\left(\mathrm{p}=3.18 \times 10^{-15}\right)$ and weight $\left(\mathrm{p}=2.66 \times 10^{-8}\right)$. Coffee-PRS was also positively associated with glycated haemoglobin $(\mathrm{HbA} 1 \mathrm{c}, \mathrm{p}=$ $\left.3.28 \times 10^{-6}\right)$ and diabetes $\left(\mathrm{p}=2.00 \times 10^{-4}\right)$. Lastly, coffee-PRS also showed a trend of negative association with ovarian cancer $\left(\mathrm{p}=4.80 \times 10^{-2}\right)$.

\section{Causal relationship between the consumption of caffeine and non-caffeine components in coffee and metabolic traits}

We set out to examine which components in coffee may lead to the potential detrimental effects of coffee consumption on metabolic perturbations. We conducted TSMR using 38 SNPs (Supplementary Table 10) from GWAS 2 and 83 SNPs (Supplementary Table 11) from GWAS 3 with $p<10^{-5}$ as a liberal cut-off for selecting the IVs, to examine the effects of caffeine or other non-caffeine components in coffee on coffee-consumption associated metabolic traits identified in the aforementioned TSMR analysis. We found that caffeine exposure was negatively associated with concentration of chylomicrons 
medRxiv preprint doi: https://doi.org/10.1101/2021.03.08.21253114; this version posted March 9, 2021. The copyright holder for this preprint (which was not certified by peer review) is the author/funder, who has granted medRxiv a license to display the preprint in perpetuity.

It is made available under a CC-BY 4.0 International license .

and largest VLDL particles (id=958, beta $=-1.128 \mathrm{SD}, \mathrm{p}=2.76 \times 10^{-2}$ ), and concentration of medium VLDL particles $\left(\mathrm{id}=913\right.$, beta $\left.=-0.976 \mathrm{SD}, \mathrm{p}=3.18 \times 10^{-2}\right)$. While the intake of other components in coffee increased the total cholesterol in LDL ( $\mathrm{id}=895$, beta $\left.=0.320, \mathrm{p}=3.50 \times 10^{-2}\right)($ Supplementary Table 12$)$. 
medRxiv preprint doi: https://doi.org/10.1101/2021.03.08.21253114; this version posted March 9, 2021. The copyright holder for this preprint (which was not certified by peer review) is the author/funder, who has granted medRxiv a license to display the preprint in perpetuity.

It is made available under a CC-BY 4.0 International license.

\section{Discussion}

We performed the largest-to-date GWA and meta-analysis on coffee consumption. We further for the first time conducted GWA studies on caffeine intake and decaffeinated coffee intake. Our analyses identified novel loci associated with each of the three phenotypes, which provide new insights into the genetic basis underlying the coffee consumption behavior among human populations. Moreover, by leveraging these genetic findings, we performed large-scale MR analyses to assess the causal relationship between different coffee intake behavior and the health outcomes. Our study indicated that, unlike what have found in many observational studies ${ }^{1-4 ; 32}$, coffee consumption may causally lead to increased risks for metabolic diseases, and the more coffee consumed, the worse the outcomes. This finding is consistent with several studies based on $\mathrm{RCTs}^{5-9}$, having important implications for public health.

In our GWA studies, we confirmed all 10 known $^{11}$ and newly identified 9 genetic loci associated with coffee consumption among a large, combined European population. A recent GWAS also using UKBB samples identified fewer loci associated with coffee consumption ${ }^{25}$. The discrepancy between this GWAS $^{25}$ and our coffee consumption GWAS 1 may be attributed to the sample selection and inclusion of different covariates. The former study included both coffee and non-coffee drinkers in UKBB European population $^{25}$, while our GWAS 1 was restricted to the coffee drinkers of European-ancestry.

Furthermore, statistical models of the former adjusted for age, sex, BMI and top 20 principal components $^{25}$, while our statistical models additionally adjusted for coffee type and smoking. These settings allow us to combine the CCGC GWAS study to perform the meta-analysis. In addition, we also identify 2 and 5 novel loci significantly associated with caffeine and non-caffeine coffee components. The enrichment analysis of the genes whose transcription is associated with these SNPs revealed pathways related to small molecule metabolic process, xenobiotic metabolic process, oxygenase p450 pathway, etc., highlighted that genetic variants altering the metabolism of caffeine and related active xenobiotic compounds in coffee are likely the major determinants for coffee consumption behaviors. 
medRxiv preprint doi: https://doi.org/10.1101/2021.03.08.21253114; this version posted March 9, 2021. The copyright holder for this preprint (which was not certified by peer review) is the author/funder, who has granted medRxiv a license to display the preprint in perpetuity.

It is made available under a CC-BY 4.0 International license.

This is consistent with the previous identification ${ }^{11}$. Meanwhile, these GWAS SNP-regulated genes are enriched in the liver and heart tissue, with also a significant enrichment related to the generation of precursor metabolites and energy (Figure 4), suggesting a potentially overlap between the coffee consumption and energy metabolism. In addition, our genome-wide meta-analysis of coffee consumption identified candidate SNPs that may have deleterious impacts (CADD score >12.37) on gene functions. In particular, rs12898397-C (CADD score =24.2), a missense variant with deleterious impact on $U L K 3$ (Unc-51 like kinase 3), was associated with increased coffee consumption but decreased expression of $U L K 3$. ULK3 is a serine/threonine protein kinase that acts as a regulator of sonic hedgehog $(\mathrm{SHH})$ signaling and autophagy. ULK3 low expression may induce the dysregulation of autophagy, which participates in controlling the metabolic functions of liver via multiple ways ${ }^{33}$.

We performed GWA studies on caffeine consumption and non-caffeine substances consumption, which have never been investigated at the genome-wide level. We found that rs112764911 (SORCS2) and rs13107325 (SLC39A8) were associated with caffeine consumption, and the latter may be also associated with coffee consumption $\left(\mathrm{p}=2.48 \times 10^{-4}\right)$. Interestingly both genes were identified among a number of GWA studies to be associated with multiple phenotypes especially neuropsychiatric diseases and traits, e.g. SNPs in SORCS2 are highly expressed in the brain tissue, and previously was associated with attention function in attention deficit hyperactive disorder ${ }^{34}$, general risk tolerance and risk behavior $^{35}$, alcohol withdrawal symptom ${ }^{36}$, depressive and manic episodes in bipolar disorder ${ }^{37}$, etc.; while SNPs in SLC39A8 were also associated with schizophrenia ${ }^{38}$, bipolar disorder ${ }^{39}$, and intelligence ${ }^{40}$, etc., indicating the impact of caffeine on central nerve system and the potential connection between caffeine intake and neuropsychiatric reactions. In addition, we identified 5 loci (LINC02060, AHR, PRR4, CYP1A1, and FTO) associated with drinking of decaffeinated coffee. Two of them (AHR and $C Y P 1 A 1)$ are also associated with coffee consumption in GWAS. AHR is known to be activated by many xenobiotic compounds, e.g. polycyclic aromatic hydrocarbons (PAHs) in coffee ${ }^{41}$. AHR response elements reside in the bidirectional promoter region located at chromosome 15q24, which associated with transcriptional activation of both $C Y P 1 A 1$ and $C Y P 1 A 2^{42-44}$. While CYP1A1 plays an important 
medRxiv preprint doi: https://doi.org/10.1101/2021.03.08.21253114; this version posted March 9, 2021. The copyright holder for this preprint (which was not certified by peer review) is the author/funder, who has granted medRxiv a license to display the preprint in perpetuity.

It is made available under a CC-BY 4.0 International license .

role in metabolizing and the detoxification of PAHs, CYP1A2 directly metabolizes caffeine ${ }^{45}$, which may explain the overlapping identification between the two GWA studies. In addition, the FTO gene is known to be associated with BMI and involved in energy metabolism, further indicated the close connection between coffee intake and energy intake/homeostasis. Our study warrants continued investigations for the detailed mechanism underlying how these genes determining the caffeine or decaffeinated coffee intake.

In order to investigate the potential impact of regular consumption of coffee, caffeine or non-caffeine coffee constituents on human health, we performed MR analyses and found that coffee consumption may causally lead to altered risks for multiple clinical outcomes which are enriched in metabolic perturbations, especially increased risks for dyslipidemia, obesity, and diabetes. Meanwhile, non-caffeine substances consumption increased the risks for high blood lipids, while caffeine consumption decreased the risks for high blood lipids. The impact of coffee on human health has been long speculated to be attributed to the various bioactive components contained in coffee, such as caffeine, chlorogenic acid, diterpenoids, PAHs, etc. In general, due to the bitter taste of coffee, coffee consumption is more likely to be associated with increased intake of sugary, thereby increase the risk of diabetes and obesity ${ }^{46 ; 47}$. Meanwhile, after consumers switch from caffeinated coffee to decaffeinated coffee, LDL cholesterol and apolipoprotein B increase, suggesting that other coffee components other than caffeine may be responsible for the high blood lipids ${ }^{48}$. Consistent with our findings, caffeine has been demonstrated to have a beneficial impact on lipid metabolism, which reduces intrahepatic lipid content and stimulates $\beta$-oxidation in hepatic cells and liver via regulating the autophagy-lysosomal pathway signaling ${ }^{49}$. While, diterpenoids contained in coffee may be an important factor leading to the increase of blood lipid level, and its impact on increasing blood lipid level may be related to its impact on the activity of serum lipid transporters ${ }^{50}$. A study tested the effect of cafestol, a diterpenoid in coffee, by giving to 10 healthy male volunteers for 28 days. Relative to baseline values, cafestol raised the activity of cholesterylester transfer protein by $18+/-12 \%$ and of phospholipid transfer protein by $21+/-$ $14 \%$ (both $\mathrm{P}<0.001$ ), which may be associated with elevated serum VLDL and LDL cholesterol ${ }^{50}$. 
medRxiv preprint doi: https://doi.org/10.1101/2021.03.08.21253114; this version posted March 9, 2021. The copyright holder for this preprint (which was not certified by peer review) is the author/funder, who has granted medRxiv a license to display the preprint in perpetuity.

It is made available under a CC-BY 4.0 International license .

Furthermore, filtered coffee containing a relative lower amount of diterpenoids does not increase blood lipid levels ${ }^{51 ; 52}$. In addition, an observational study showed that C-peptide, a marker of insulin secretion, decreased with every additional cup of decaffeinated coffee $(0.063 \mathrm{ng} / \mathrm{ml} ; \mathrm{P}=0.0003)$, which indicated the potential function of non-caffeine substances for diabetic risk ${ }^{53}$. Taken together, our data suggest that the detrimental effects of coffee consumption on health outcomes may be due to the intake of non-caffeine components. While even though caffeine may exert some beneficial impact on lipids homeostasis, this impact may not be sufficient to compensate the deleterious effects of the non-caffeine components in the coffee. The detailed mechanism underlying the association between coffee consumption and metabolic perturbations remains to be further investigated.

It is noteworthy that our MR analyses also suggested a potential causal relationship between coffee consumption and ovarian cancer, with an opposing risk for different subtypes of the disease. While the detailed mechanism underlying this association remains unclear. Also, caffeine has also been demonstrated to decrease estrogen but increase progesterone, which has been weakly associated with ovarian cancer risk ${ }^{54 ; 55}$. More studies are needed to further clarify this relationship.

\section{Limitations}

The current study was conducted in the participants of European ancestry. Whether our findings can be generalized to other ethnic groups remains to be validated in future studies. Moreover, although the study has identified 19 genomic loci (9 of which are novel loci) associated with coffee consumption, they only explain a small proportion of the phenotype variance, indicating that our MR results were driven by a limited proportion of genetic susceptibility. Our conclusion may not represent the full image of the health impact of coffee consumption. Meanwhile, the findings of GWAS 2 and 3 studies need further independent validations as well.

\section{Conclusions}


medRxiv preprint doi: https://doi.org/10.1101/2021.03.08.21253114; this version posted March 9, 2021. The copyright holder for this preprint (which was not certified by peer review) is the author/funder, who has granted medRxiv a license to display the preprint in perpetuity.

It is made available under a CC-BY 4.0 International license.

This study identified novel genetic loci associated with multiple coffee consumption behaviors and provided evidence that coffee consumption increases the risk for metabolic diseases. This could have significant implications for global public health given the increasing burden of metabolic diseases.

\section{Acknowledgements}

This work was supported by the "Changbai Mountain Scholar" Distinguished Professor Awarding Program of the Department of Education of Jilin Province, China. This work was supported in part by the Start-Up Fund (W.L) of the Wayne State University.

\section{Author contributions}

J.L, W.L and P.C conceived the study. P.C contributed to the acquisition of UKBB data. J.L, M.Z and L.C analyzed the data. J.L, W.L, J.W and P.C interpreted the results. J.L, T.C and W.L wrote the first draft of the manuscript. All authors revised the manuscript and approved the submission. 
medRxiv preprint doi: https://doi.org/10.1101/2021.03.08.21253114; this version posted March 9, 2021. The copyright holder for this preprint (which was not certified by peer review) is the author/funder, who has granted medRxiv a license to display the preprint in perpetuity.

It is made available under a CC-BY 4.0 International license .

\section{References}

1. Ding, M., Bhupathiraju, S.N., Satija, A., van Dam, R.M., and Hu, F.B. (2014). Long-term coffee consumption and risk of cardiovascular disease: a systematic review and a dose-response meta-analysis of prospective cohort studies. Circulation 129, 643-659.

2. Ding, M., Bhupathiraju, S.N., Chen, M., van Dam, R.M., and Hu, F.B. (2014). Caffeinated and decaffeinated coffee consumption and risk of type 2 diabetes: a systematic review and a dose-response meta-analysis. Diabetes care $37,569-586$.

3. Nordestgaard, A.T., Thomsen, M., and Nordestgaard, B.G. (2015). Coffee intake and risk of obesity, metabolic syndrome and type 2 diabetes: a Mendelian randomization study. International journal of epidemiology 44 , 551-565.

4. Poole, R., Kennedy, O.J., Roderick, P., Fallowfield, J.A., Hayes, P.C., and Parkes, J. (2017). Coffee consumption and health: umbrella review of meta-analyses of multiple health outcomes. BMJ 359, j5024.

5. Lane, J.D., Feinglos, M.N., and Surwit, R.S. (2008). Caffeine increases ambulatory glucose and postprandial responses in coffee drinkers with type 2 diabetes. Diabetes care 31, 221-222.

6. Greenberg, J.A., Owen, D.R., and Geliebter, A. (2010). Decaffeinated coffee and glucose metabolism in young men. Diabetes care 33, 278-280.

7. Corrêa, T.A., Rogero, M.M., Mioto, B.M., Tarasoutchi, D., Tuda, V.L., César, L.A., and Torres, E.A. (2013). Paper-filtered coffee increases cholesterol and inflammation biomarkers independent of roasting degree: a clinical trial. Nutrition (Burbank, Los Angeles County, Calif) 29, 977-981.

8. van Dam, R.M., Pasman, W.J., and Verhoef, P. (2004). Effects of coffee consumption on fasting blood glucose 
medRxiv preprint doi: https://doi.org/10.1101/2021.03.08.21253114; this version posted March 9, 2021. The copyright holder for this preprint (which was not certified by peer review) is the author/funder, who has granted medRxiv a license to display the preprint in perpetuity.

It is made available under a CC-BY 4.0 International license .

and insulin concentrations: randomized controlled trials in healthy volunteers. Diabetes care 27 , 2990-2992.

9. Nicolopoulos, K., Mulugeta, A., Zhou, A., and Hyppönen, E. (2020). Association between habitual coffee consumption and multiple disease outcomes: A Mendelian randomisation phenome-wide association study in the UK Biobank. Clin Nutr.

10. Zhang, Y., Liu, Z., Choudhury, T., Cornelis, M.C., and Liu, W. (2020). Habitual coffee intake and risk for nonalcoholic fatty liver disease: a two-sample Mendelian randomization study. European journal of nutrition.

11. Cornelis, M.C., Byrne, E.M., Esko, T., Nalls, M.A., Ganna, A., Paynter, N., Monda, K.L., Amin, N., Fischer, K., Renstrom, F., et al. (2015). Genome-wide meta-analysis identifies six novel loci associated with habitual coffee consumption. Molecular psychiatry 20, 647-656.

12. Sudlow, C., Gallacher, J., Allen, N., Beral, V., Burton, P., Danesh, J., Downey, P., Elliott, P., Green, J., Landray, M., et al. (2015). UK biobank: an open access resource for identifying the causes of a wide range of complex diseases of middle and old age. PLoS Med 12, e1001779.

13. Bycroft, C., Freeman, C., Petkova, D., Band, G., Elliott, L.T., Sharp, K., Motyer, A., Vukcevic, D., Delaneau, O., O'Connell, J., et al. (2018). The UK Biobank resource with deep phenotyping and genomic data. Nature 562, 203-209.

14. McCarthy, S., Das, S., Kretzschmar, W., Delaneau, O., Wood, A.R., Teumer, A., Kang, H.M., Fuchsberger, C., Danecek, P., Sharp, K., et al. (2016). A reference panel of 64,976 haplotypes for genotype imputation. Nature genetics $48,1279-1283$. 
medRxiv preprint doi: https://doi.org/10.1101/2021.03.08.21253114; this version posted March 9, 2021. The copyright holder for this preprint (which was not certified by peer review) is the author/funder, who has granted medRxiv a license to display the preprint in perpetuity.

It is made available under a CC-BY 4.0 International license .

15. Watanabe, K., Taskesen, E., van Bochoven, A., and Posthuma, D. (2017). Functional mapping and annotation

of genetic associations with FUMA. Nature communications 8, 1826.

16. Hemani, G., Zheng, J., Elsworth, B., Wade, K.H., Haberland, V., Baird, D., Laurin, C., Burgess, S., Bowden, J., Langdon, R., et al. (2018). The MR-Base platform supports systematic causal inference across the human phenome. elife 7.

17. Willer, C.J., Li, Y., and Abecasis, G.R. (2010). METAL: fast and efficient meta-analysis of genomewide association scans. Bioinformatics (Oxford, England) 26, 2190-2191.

18. Kircher, M., Witten, D.M., Jain, P., O'Roak, B.J., Cooper, G.M., and Shendure, J. (2014). A general framework for estimating the relative pathogenicity of human genetic variants. Nature genetics $46,310-315$.

19. (2015). Human genomics. The Genotype-Tissue Expression (GTEx) pilot analysis: multitissue gene regulation in humans. Science (New York, NY) 348, 648-660.

20. Benjamini, Y., and Hochberg, Y. (1995). Controlling the False Discovery Rate: A Practical and Powerful Approach to Multiple Testing. 57, 289-300.

21. Staley, J.R., Blackshaw, J., Kamat, M.A., Ellis, S., Surendran, P., Sun, B.B., Paul, D.S., Freitag, D., Burgess, S., Danesh, J., et al. (2016). PhenoScanner: a database of human genotype-phenotype associations. Bioinformatics (Oxford, England) 32, 3207-3209.

22. Kamat, M.A., Blackshaw, J.A., Young, R., Surendran, P., Burgess, S., Danesh, J., Butterworth, A.S., and Staley, J.R. (2019). PhenoScanner V2: an expanded tool for searching human genotype-phenotype associations. Bioinformatics (Oxford, England) 35, 4851-4853.

23. Yang, J., Lee, S.H., Goddard, M.E., and Visscher, P.M. (2011). GCTA: a tool for genome-wide complex trait 
medRxiv preprint doi: https://doi.org/10.1101/2021.03.08.21253114; this version posted March 9, 2021. The copyright holder for this preprint (which was not certified by peer review) is the author/funder, who has granted medRxiv a license to display the preprint in perpetuity.

It is made available under a CC-BY 4.0 International license .

analysis. American journal of human genetics $88,76-82$.

24. Choi, S.W., and O'Reilly, P.F. (2019). PRSice-2: Polygenic Risk Score software for biobank-scale data.

GigaScience 8.

25. Zhong, V.W., Kuang, A., Danning, R.D., Kraft, P., van Dam, R.M., Chasman, D.I., and Cornelis, M.C. (2019). A

genome-wide association study of bitter and sweet beverage consumption. Human molecular genetics 28 , 2449-2457.

26. In. (

27. Locke, A.E., Kahali, B., Berndt, S.I., Justice, A.E., Pers, T.H., Day, F.R., Powell, C., Vedantam, S., Buchkovich, M.L., Yang, J., et al. (2015). Genetic studies of body mass index yield new insights for obesity biology. Nature 518, 197-206.

28. Teslovich, T.M., Musunuru, K., Smith, A.V., Edmondson, A.C., Stylianou, I.M., Koseki, M., Pirruccello, J.P., Ripatti, S., Chasman, D.I., Willer, C.J., et al. (2010). Biological, clinical and population relevance of 95 loci for blood lipids. Nature 466, 707-713.

29. Wood, A.R., Esko, T., Yang, J., Vedantam, S., Pers, T.H., Gustafsson, S., Chu, A.Y., Estrada, K., Luan, J., Kutalik, Z., et al. (2014). Defining the role of common variation in the genomic and biological architecture of adult human height. Nature genetics $46,1173-1186$.

30. Neale, B.M. UK Biobank GWAS. In. (http://www.nealelab.is/uk-biobank.

31. Gaulton, K.J., Ferreira, T., Lee, Y., Raimondo, A., Mägi, R., Reschen, M.E., Mahajan, A., Locke, A., Rayner, N.W., Robertson, N., et al. (2015). Genetic fine mapping and genomic annotation defines causal mechanisms at type 2 diabetes susceptibility loci. Nature genetics 47, 1415-1425. 
medRxiv preprint doi: https://doi.org/10.1101/2021.03.08.21253114; this version posted March 9, 2021. The copyright holder for this preprint (which was not certified by peer review) is the author/funder, who has granted medRxiv a license to display the preprint in perpetuity.

It is made available under a CC-BY 4.0 International license .

32. Kim, Y., Je, Y., and Giovannucci, E. (2019). Coffee consumption and all-cause and cause-specific mortality: a meta-analysis by potential modifiers. European journal of epidemiology 34, 731-752.

33. Madrigal-Matute, J., and Cuervo, A.M. (2016). Regulation of Liver Metabolism by Autophagy. Gastroenterology $150,328-339$.

34. Alemany, S., Ribases, M., Vilor-Tejedor, N., Bustamante, M., Sanchez-Mora, C., Bosch, R., Richarte, V., Cormand, B., Casas, M., Ramos-Quiroga, J.A., et al. (2015). New suggestive genetic loci and biological pathways for attention function in adult attention-deficit/hyperactivity disorder. Am J Med Genet B Neuropsychiatr Genet 168, 459-470.

35. Karlsson Linner, R., Biroli, P., Kong, E., Meddens, S.F.W., Wedow, R., Fontana, M.A., Lebreton, M., Tino, S.P., Abdellaoui, A., Hammerschlag, A.R., et al. (2019). Genome-wide association analyses of risk tolerance and risky behaviors in over 1 million individuals identify hundreds of loci and shared genetic influences. Nat Genet 51, 245-257.

36. Smith, A.H., Ovesen, P.L., Skeldal, S., Yeo, S., Jensen, K.P., Olsen, D., Diazgranados, N., Zhao, H., Farrer, L.A., Goldman, D., et al. (2018). Risk Locus Identification Ties Alcohol Withdrawal Symptoms to SORCS2. Alcohol Clin Exp Res 42, 2337-2348.

37. Fabbri, C., and Serretti, A. (2016). Genetics of long-term treatment outcome in bipolar disorder. Prog Neuropsychopharmacol Biol Psychiatry 65, 17-24.

38. Goes, F.S., McGrath, J., Avramopoulos, D., Wolyniec, P., Pirooznia, M., Ruczinski, I., Nestadt, G., Kenny, E.E., Vacic, V., Peters, I., et al. (2015). Genome-wide association study of schizophrenia in Ashkenazi Jews. American journal of medical genetics Part B, Neuropsychiatric genetics : the official publication of the 
medRxiv preprint doi: https://doi.org/10.1101/2021.03.08.21253114; this version posted March 9, 2021. The copyright holder for this preprint (which was not certified by peer review) is the author/funder, who has granted medRxiv a license to display the preprint in perpetuity.

It is made available under a CC-BY 4.0 International license .

International Society of Psychiatric Genetics 168, 649-659.

39. Wu, Y., Cao, H., Baranova, A., Huang, H., Li, S., Cai, L., Rao, S., Dai, M., Xie, M., Dou, Y., et al. (2020).

Multi-trait analysis for genome-wide association study of five psychiatric disorders. Translational psychiatry 10, 209.

40. Savage, J.E., Jansen, P.R., Stringer, S., Watanabe, K., Bryois, J., de Leeuw, C.A., Nagel, M., Awasthi, S., Barr, P.B., Coleman, J.R.I., et al. (2018). Genome-wide association meta-analysis in 269,867 individuals identifies new genetic and functional links to intelligence. Nature genetics 50, 912-919.

41. Ishikawa, T., Takahashi, S., Morita, K., Okinaga, H., and Teramoto, T. (2014). Induction of AhR-mediated gene transcription by coffee. PloS one 9, e102152.

42. Jorge-Nebert, L.F., Jiang, Z., Chakraborty, R., Watson, J., Jin, L., McGarvey, S.T., Deka, R., and Nebert, D.W. (2010). Analysis of human CYP1A1 and CYP1A2 genes and their shared bidirectional promoter in eight world populations. $31,27-40$.

43. Jorge-Nebert, L.F., Jiang, Z., Chakraborty, R., Watson, J., Jin, L., McGarvey, S.T., Deka, R., and Nebert, D.W. (2010). Analysis of human CYP1A1 and CYP1A2 genes and their shared bidirectional promoter in eight world populations. Human mutation 31, 27-40.

44. Ueda, R., Iketaki, H., Nagata, K., Kimura, S., Gonzalez, F.J., Kusano, K., Yoshimura, T., and Yamazoe, Y. (2006). A common regulatory region functions bidirectionally in transcriptional activation of the human CYP1A1 and CYP1A2 genes. Molecular pharmacology 69, 1924-1930.

45. Kot, M., and Daniel, W.A. (2008). The relative contribution of human cytochrome P450 isoforms to the four caffeine oxidation pathways: an in vitro comparative study with cDNA-expressed P450s including CYP2C 
medRxiv preprint doi: https://doi.org/10.1101/2021.03.08.21253114; this version posted March 9, 2021. The copyright holder for this preprint (which was not certified by peer review) is the author/funder, who has granted medRxiv a license to display the preprint in perpetuity. It is made available under a CC-BY 4.0 International license .

isoforms. Biochemical pharmacology 76, 543-551.

46. Keast, R.S., Sayompark, D., Sacks, G., Swinburn, B.A., and Riddell, L.J. (2011). The influence of caffeine on energy content of sugar-sweetened beverages: 'the caffeine-calorie effect'. European journal of clinical nutrition $65,1338-1344$.

47. Keast, R.S., Swinburn, B.A., Sayompark, D., Whitelock, S., and Riddell, L.J. (2015). Caffeine increases sugar-sweetened beverage consumption in a free-living population: a randomised controlled trial. The British journal of nutrition 113, 366-371.

48. Superko, H.R., Bortz, W., Jr., Williams, P.T., Albers, J.J., and Wood, P.D. (1991). Caffeinated and decaffeinated coffee effects on plasma lipoprotein cholesterol, apolipoproteins, and lipase activity: a controlled, randomized trial. The American journal of clinical nutrition 54, 599-605.

49. Sinha, R.A., Farah, B.L., Singh, B.K., Siddique, M.M., Li, Y., Wu, Y., Ilkayeva, O.R., Gooding, J., Ching, J., Zhou, J., et al. (2014). Caffeine stimulates hepatic lipid metabolism by the autophagy-lysosomal pathway in mice. Hepatology (Baltimore, Md) 59, 1366-1380.

50. van Tol, A., Urgert, R., de Jong-Caesar, R., van Gent, T., Scheek, L.M., de Roos, B., and Katan, M.B. (1997). The cholesterol-raising diterpenes from coffee beans increase serum lipid transfer protein activity levels in humans. Atherosclerosis 132, 251-254.

51. Kurzrock, T., and Speer, K. (2007). Diterpenes and Diterpene Esters in Coffee. Food Reviews International 17, 433-450.

52. Jee, S.H., He, J., Appel, L.J., Whelton, P.K., Suh, I., and Klag, M.J. (2001). Coffee consumption and serum lipids: a meta-analysis of randomized controlled clinical trials. American journal of epidemiology 153, 
medRxiv preprint doi: https://doi.org/10.1101/2021.03.08.21253114; this version posted March 9, 2021. The copyright holder for this preprint (which was not certified by peer review) is the author/funder, who has granted medRxiv a license to display the preprint in perpetuity.

It is made available under a CC-BY 4.0 International license.

353-362.

53. Wu, T., Willett, W.C., Hankinson, S.E., and Giovannucci, E. (2005). Caffeinated coffee, decaffeinated coffee, and caffeine in relation to plasma C-peptide levels, a marker of insulin secretion, in U.S. women. Diabetes care $28,1390-1396$.

54. Kotsopoulos, J., Eliassen, A.H., Missmer, S.A., Hankinson, S.E., and Tworoger, S.S. (2009). Relationship between caffeine intake and plasma sex hormone concentrations in premenopausal and postmenopausal women. Cancer 115, 2765-2774.

55. Beral, V., Gaitskell, K., Hermon, C., Moser, K., Reeves, G., and Peto, R. (2015). Menopausal hormone use and ovarian cancer risk: individual participant meta-analysis of 52 epidemiological studies. Lancet (London, England) 385, 1835-1842. 
medRxiv preprint doi: https://doi.org/10.1101/2021.03.08.21253114; this version posted March 9, 2021. The copyright holder for this preprint (which was not certified by peer review) is the author/funder, who has granted medRxiv a license to display the preprint in perpetuity.

It is made available under a CC-BY 4.0 International license.

\section{Figure and table legends:}

Figure 1. A schematic diagram of the study design.

Figure 2. The Manhattan plot displays the genome-wide associations between SNPs and coffee consumption (A), caffeine consumption (B), and non-caffeine substances consumption (C). The $\mathrm{x}$-axis represents genomic position of variants. The $y$-axis shows the strength of the associations $\left(-\log _{10} \mathrm{P}\right)$. The dash line indicates the genome wide significance level of $\mathrm{p}=5 \mathrm{e}-8$

Figure 3. Pathway enrichment of the 180 genes associated with GWAS identified SNPs. The enrichment analysis was performed using GENE2FUNC in FUMA. The top 10 significantly enrichments (adjusted $\mathrm{P}<0.05)$ were available in the plot.

Figure 4. Expression enrichment analyses of the 180 genes associated with GWAS-identified SNPs. The tissue specific gene expression enrichment was analyzed using TSEA. Genes were significantly enriched in the liver and heart tissue (FDR $<0.1)$.

Figure 5. The enrichment analysis of the outcomes causally associated with the genetically driven coffee consumption among the phenotypic categories of various traits defined in MR-Base. For each category, the $-\log _{10}$ of the enrichment $\mathrm{p}$ value was indicated on the left, while the enriched fold change was indicated on the right. The phenotype categories with FDR $\leq 0.05$ are highlighted in dark red. 
medRxiv preprint doi: https://doi.org/10.1101/2021.03.08.21253114; this version posted March 9, 2021. The copyright holder for this preprint (which was not certified by peer review) is the author/funder, who has granted medRxiv a license to display the preprint in perpetuity.

It is made available under a CC-BY 4.0 International license .

\section{Figure 1.}




medRxiv preprint doi: https://doi.org/10.1101/2021.03.08.21253114; this version posted March 9, 2021. The copyright holder for this preprint (which was not certified by peer review) is the author/funder, who has granted medRxiv a license to display the preprint in perpetuity.

It is made available under a CC-BY 4.0 International license .

Figure 2.

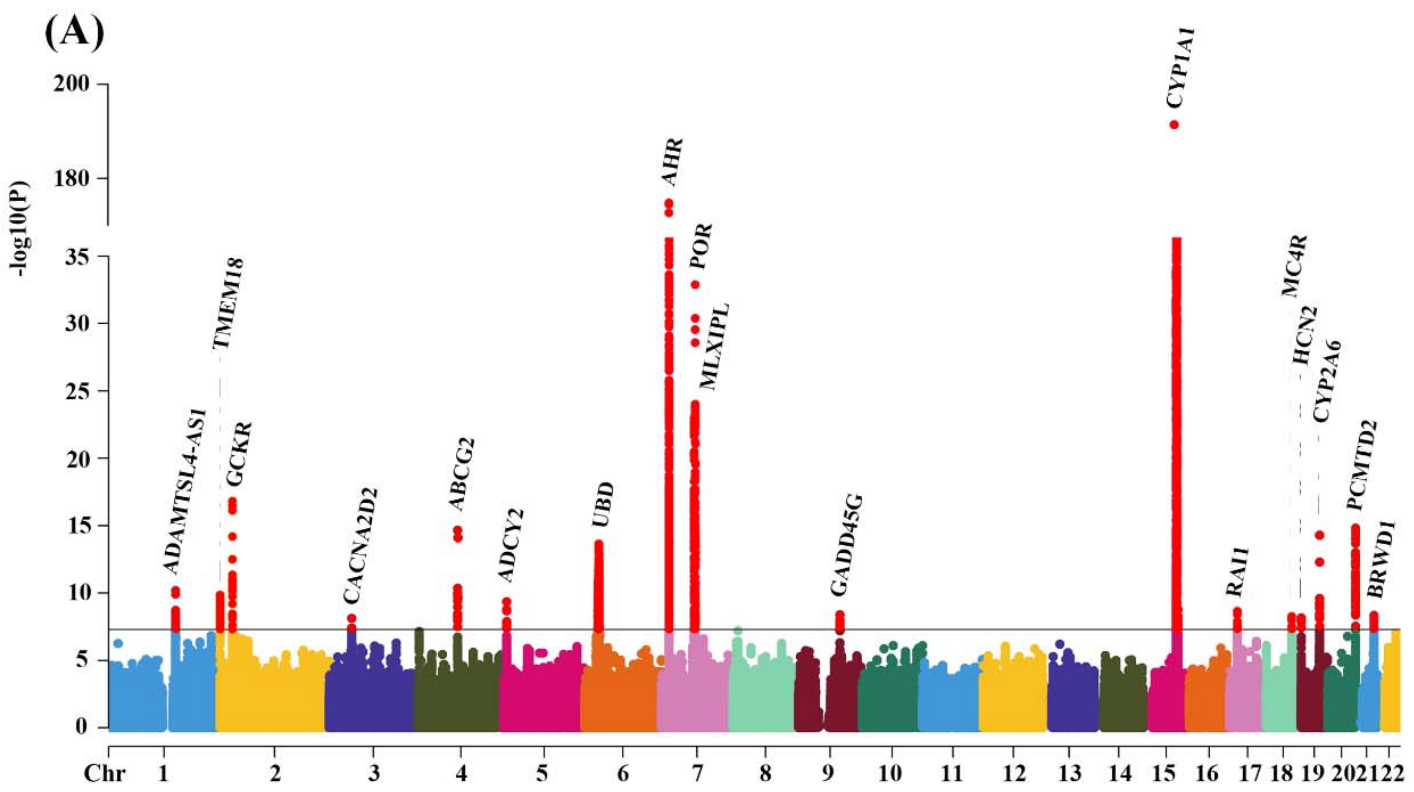

(B)



(C)

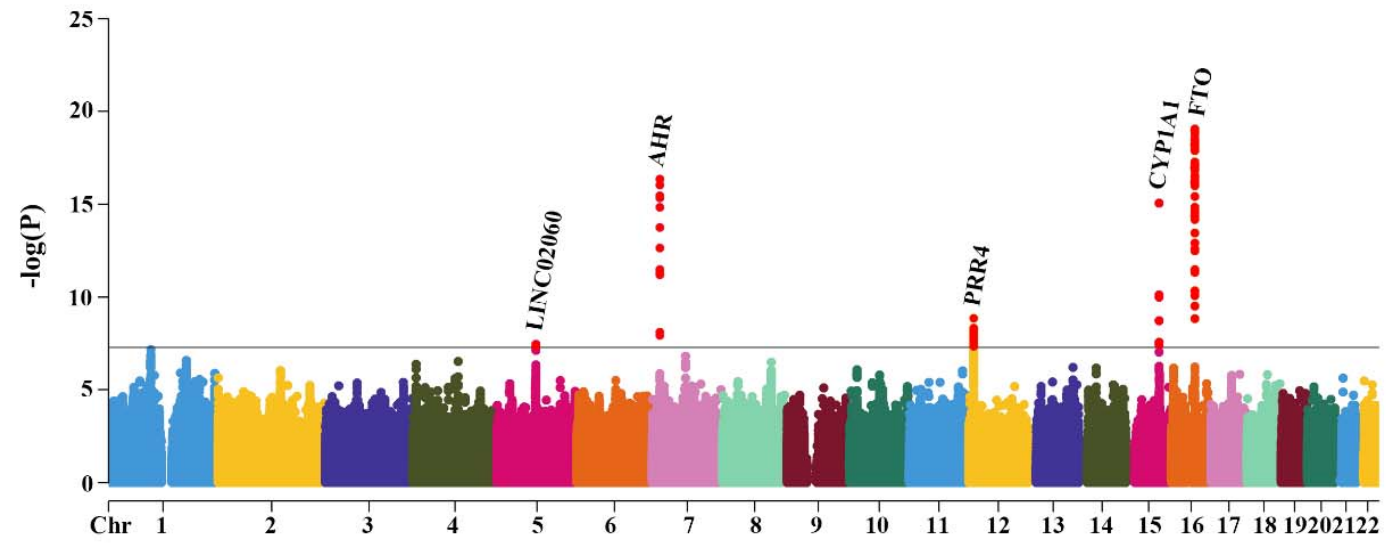


medRxiv preprint doi: https://doi.org/10.1101/2021.03.08.21253114; this version posted March 9, 2021. The copyright holder for this preprint (which was not certified by peer review) is the author/funder, who has granted medRxiv a license to display the preprint in perpetuity.

It is made available under a CC-BY 4.0 International license.

\section{Figure 3.}

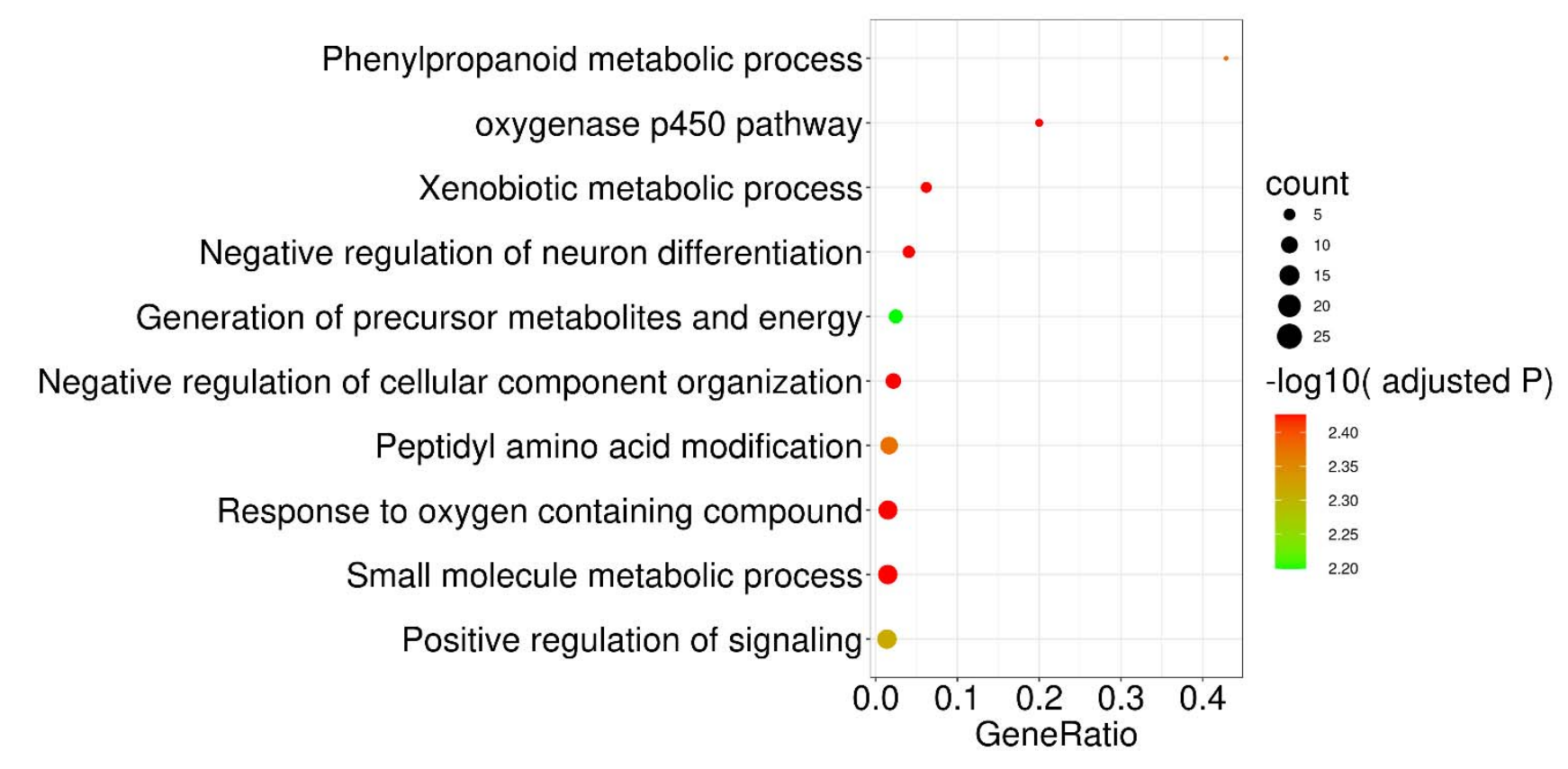


medRxiv preprint doi: https://doi.org/10.1101/2021.03.08.21253114; this version posted March 9, 2021. The copyright holder for this preprint (which was not certified by peer review) is the author/funder, who has granted medRxiv a license to display the preprint in perpetuity.

It is made available under a CC-BY 4.0 International license.

Figure 4.

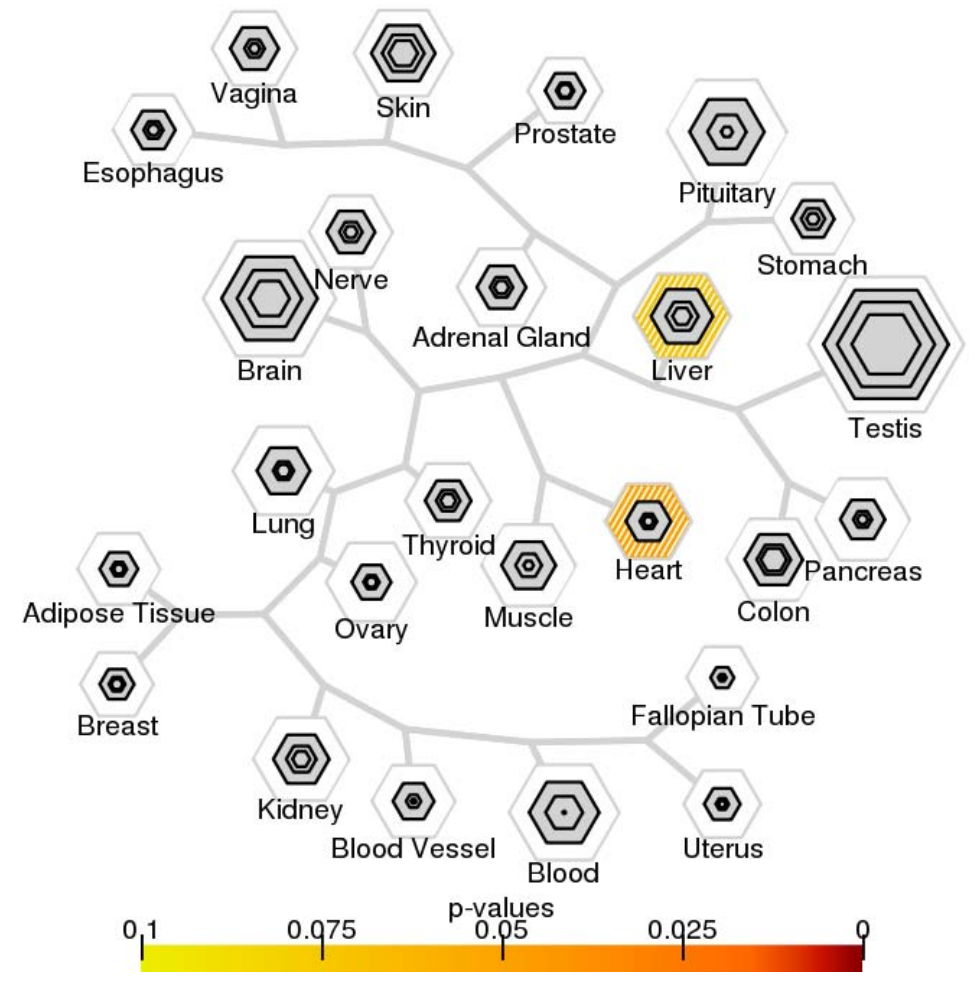


medRxiv preprint doi: https://doi.org/10.1101/2021.03.08.21253114; this version posted March 9, 2021. The copyright holder for this preprint (which was not certified by peer review) is the author/funder, who has granted medRxiv a license to display the preprint in perpetuity.

It is made available under a CC-BY 4.0 International license .

Figure 5.

$-\log (\mathbf{P})$

14.93

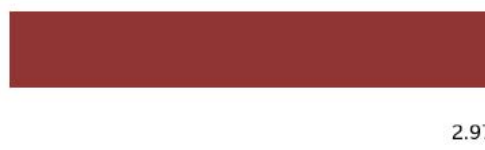

2.97

1.76

1.29

0.65

0.47

0.4

0.31

0.27
Phenotype category

Blood lipids

Fatty acid

Anthropometric

Urate

Kidney

Cofactors and vitamins

Metabolites ratio

Energy

Hormone
Fold_change

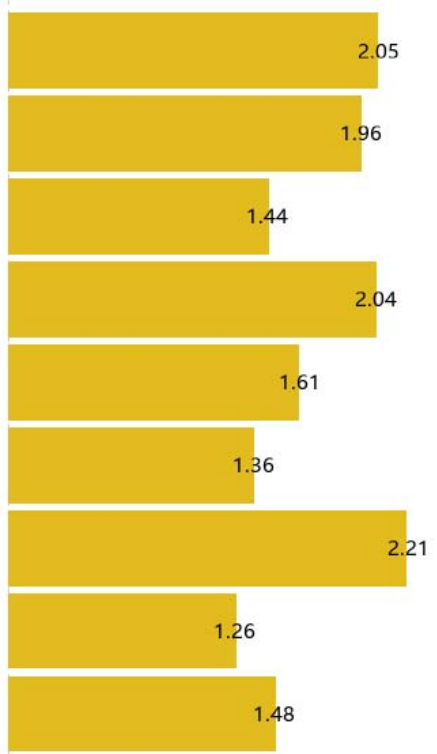


Table 1. The Top SNPs significantly associated with coffee consumption, caffeine consumption, and non-caffeine substances consumption, respectively.

\begin{tabular}{|c|c|c|c|c|c|c|c|c|c|c|c|c|c|c|c|c|}
\hline \multirow[b]{2}{*}{ Phenotype } & \multirow[b]{2}{*}{ Locus } & \multirow[b]{2}{*}{ Top lead SNP } & \multirow[b]{2}{*}{ CHR } & \multirow[b]{2}{*}{ POS } & \multirow[b]{2}{*}{ EA/NEA } & \multirow[b]{2}{*}{ MAF } & \multirow[b]{2}{*}{ nearestGene } & \multicolumn{3}{|c|}{ GWAS $\mathrm{X}$} & \multicolumn{3}{|l|}{ CCGC } & \multicolumn{3}{|c|}{ META-analysis } \\
\hline & & & & & & & & BETA & SE & $\mathrm{P}$ & BETA & SE & $\mathrm{P}$ & BETA & SE & $\mathrm{P}$ \\
\hline \multirow{19}{*}{ Coffee consumption } & 1 & rs6655975 & 1 & 150542128 & $\mathrm{~A} / \mathrm{G}$ & 0.348 & ADAMTSL4-AS1 & 0.027 & 0.005 & $1.24 \times 10^{-8}$ & 0.026 & 0.008 & $1.33 \times 10^{-3}$ & 0.027 & 0.004 & $6.33 \times 10^{-11}$ \\
\hline & 2 & rs 2867110 & 2 & 651105 & $\mathrm{C} / \mathrm{G}$ & 0.174 & LOC105373352; TMEM18 & -0.034 & 0.006 & $1.43 \times 10^{-8}$ & -0.03 & 0.01 & $2.62 \times 10^{-3}$ & -0.03 & 0.005 & $1.44 \times 10^{-10}$ \\
\hline & 3 & rs1260326 & 2 & 27730940 & $\mathrm{~T} / \mathrm{C}$ & 0.411 & GCKR & -0.031 & 0.005 & $1.40 \times 10^{-11}$ & -0.04 & 0.008 & $1.06 \times 10^{-7}$ & -0.03 & 0.004 & $1.55 \times 10^{-17}$ \\
\hline & 4 & rs1467913 & 3 & 50525017 & $\mathrm{~A} / \mathrm{C}$ & 0.123 & CACNA2D2 & -0.035 & 0.006 & $9.04 \times 10^{-8}$ & -0.02 & 0.011 & $8.07 \times 10^{-2}$ & -0.03 & 0.006 & $3.86 \times 10^{-8}$ \\
\hline & 5 & rs1481012 & 4 & 89039082 & $\mathrm{~A} / \mathrm{G}$ & 0.089 & $\mathrm{ABCG} 2$ & 0.046 & 0.007 & $1.87 \times 10^{-10}$ & 0.063 & 0.013 & $1.13 \times 10^{-6}$ & 0.05 & 0.006 & $2.25 \times 10^{-15}$ \\
\hline & 6 & rs12519880* & 5 & 7391434 & $\mathrm{~A} / \mathrm{C}$ & 0.281 & LINC02123; ADCY2 & -0.031 & 0.005 & $4.51 \times 10^{-10}$ & -0.02 & 0.008 & $6.61 \times 10^{-2}$ & -0.03 & 0.005 & $4.52 \times 10^{-10}$ \\
\hline & 7 & rs1235162 & 6 & 29537224 & $\mathrm{~A} / \mathrm{G}$ & 0.073 & UBD; SNORD32B & -0.042 & 0.007 & $7.71 \times 10^{-10}$ & -0.02 & 0.013 & $2.70 \times 10^{-1}$ & -0.04 & 0.006 & $2.17 \times 10^{-9}$ \\
\hline & 8 & rs4410790 & 7 & 17284577 & $\mathrm{~T} / \mathrm{C}$ & 0.385 & AGR3; AHR & -0.111 & 0.005 & $3.81 \times 10^{-121}$ & -0.14 & 0.009 & $1.48 \times 10^{-57}$ & -0.12 & 0.004 & $1.91 \times 10^{-175}$ \\
\hline & 9 & rs799166 & 7 & 73051932 & $\mathrm{C} / \mathrm{G}$ & 0.115 & MLXIPL; VPS37D & -0.057 & 0.007 & $1.89 \times 10^{-17}$ & -0.07 & 0.013 & $6.49 \times 10^{-8}$ & -0.06 & 0.006 & $1.08 \times 10^{-23}$ \\
\hline & 10 & rs17685 & 7 & 75616105 & $\mathrm{~A} / \mathrm{G}$ & 0.289 & POR & 0.049 & 0.005 & $3.61 \times 10^{-22}$ & 0.069 & 0.009 & $9.06 \times 10^{-14}$ & 0.054 & 0.004 & $1.35 \times 10^{-33}$ \\
\hline & 11 & rs1571536 & 9 & 92215638 & $\mathrm{~T} / \mathrm{C}$ & 0.473 & SEMA4D; GADD45G & -0.018 & 0.005 & $5.62 \times 10^{-5}$ & -0.04 & 0.008 & $2.32 \times 10^{-6}$ & -0.02 & 0.004 & $4.25 \times 10^{-9}$ \\
\hline & 12 & rs 2472297 & 15 & 75027880 & $\mathrm{~T} / \mathrm{C}$ & 0.215 & CYP1A1; CYP1A2 & 0.132 & 0.005 & $4.98 \times 10^{-147}$ & 0.146 & 0.01 & $6.45 \times 10^{-47}$ & 0.135 & 0.005 & $4.02 \times 10^{-192}$ \\
\hline & 13 & rs2667773* & 15 & 77872191 & $\mathrm{~A} / \mathrm{G}$ & 0.364 & LOC101929457; LINGO1 & 0.03 & 0.005 & $1.65 \times 10^{-9}$ & 0.023 & 0.008 & $5.40 \times 10^{-3}$ & 0.03 & 0.005 & $1.65 \times 10^{-9}$ \\
\hline & 14 & rs11078398 & 17 & 17697099 & $\mathrm{~A} / \mathrm{G}$ & 0.333 & RAI1 & -0.033 & 0.005 & $2.28 \times 10^{-9}$ & NA & NA & NA & -0.03 & 0.006 & $2.28 \times 10^{-9}$ \\
\hline & 15 & rs 476828 & 18 & 57852587 & $\mathrm{~T} / \mathrm{C}$ & 0.247 & PMAIP1; MC4R & -0.029 & 0.005 & $3.87 \times 10^{-8}$ & -0.02 & 0.009 & $2.96 \times 10^{-2}$ & -0.03 & 0.005 & $5.38 \times 10^{-9}$ \\
\hline & 16 & rs113534512 & 19 & 590172 & $\mathrm{~A} / \mathrm{G}$ & 0.456 & $\mathrm{HCN} 2$ & 0.027 & 0.005 & $7.04 \times 10^{-9}$ & NA & NA & NA & 0.027 & 0.005 & $7.04 \times 10^{-9}$ \\
\hline & 17 & rs56113850* & 19 & 41353107 & $\mathrm{~T} / \mathrm{C}$ & 0.408 & CYP2A6 & -0.036 & 0.005 & $5.13 \times 10^{-15}$ & -0.04 & 0.01 & $2.39 \times 10^{-4}$ & -0.04 & 0.005 & $5.13 \times 10^{-15}$ \\
\hline & 18 & rs6512309 & 20 & 62892584 & $\mathrm{~A} / \mathrm{G}$ & 0.438 & PCMTD2 & -0.033 & 0.005 & $9.31 \times 10^{-13}$ & -0.03 & 0.008 & $3.43 \times 10^{-4}$ & -0.03 & 0.004 & $1.54 \times 10^{-15}$ \\
\hline & 19 & rs 3945 & 21 & 40566067 & $\mathrm{~A} / \mathrm{G}$ & 0.315 & BRWD1 & -0.023 & 0.005 & $8.50 \times 10^{-7}$ & -0.03 & 0.008 & $1.32 \times 10^{-3}$ & -0.02 & 0.004 & $4.39 \times 10^{-9}$ \\
\hline \multirow{2}{*}{$\begin{array}{c}\text { Caffeine } \\
\text { consumption }\end{array}$} & 1 & rs112764911 & 4 & 7527405 & $\mathrm{~A} / \mathrm{C}$ & 0.066 & SORCS2 & -0.013 & 0.002 & $1.88 \times 10^{-8}$ & & & & & & \\
\hline & 2 & rs13107325 & 4 & 103188709 & $\mathrm{C} / \mathrm{T}$ & 0.080 & SLC39A8 & 0.015 & 0.002 & $4.12 \times 10^{-14}$ & & & & & & \\
\hline \multirow{5}{*}{$\begin{array}{l}\text { non-caffeine } \\
\text { substances } \\
\text { consumption }\end{array}$} & 1 & rs2067919 & 5 & 87783713 & $\mathrm{~T} / \mathrm{C}$ & 0.344 & LINC02060; LINC00461 & -0.011 & 0.002 & $3.63 \times 10^{-8}$ & & & & & & \\
\hline & 2 & rs4410790 & 7 & 17284577 & $\mathrm{~T} / \mathrm{C}$ & 0.385 & AGR3; AHR & -0.016 & 0.002 & $4.49 \times 10^{-17}$ & & & & & & \\
\hline & 3 & rs1201669374 & 12 & 11271915 & $\mathrm{CA} / \mathrm{C}$ & 0.14 & PRR4:TAS2R14 & 0.016 & 0.003 & $1.41 \times 10^{-9}$ & & & & & & \\
\hline & 4 & rs2472297 & 15 & 75027880 & $\mathrm{C} / \mathrm{T}$ & 0.215 & CYP1A1; CYP1A2 & -0.017 & 0.002 & $8.57 \times 10^{-16}$ & & & & & & \\
\hline & 5 & rs11642015 & 16 & 53802494 & $\mathrm{C} / \mathrm{T}$ & 0.432 & FTO & -0.017 & 0.002 & $8.93 \times 10^{-20}$ & & & & & & \\
\hline
\end{tabular}


Footnotes: Locus: Index of genomic risk loci. Top lead SNP: lead SNP which has the most significant P-value in the locus. CHR : chromosome of top lead SNP. POS: position of top lead SNP based on the human genome build hg19. EA: effect allele. NEA: non-effect allele. MAF: minor allele frequency. nearestGene: The nearest gene(s) of the SNP based on ANNOVAR annotations. BETA: regression coefficient. SE: standard error of BETA. P: the p-value. *: Since the top lead SNP rs12519880 (A/C) from the GWAS 1 was not present in the CCGC GWAS, the variant $\mathrm{rs} 12514566(\mathrm{~A} / \mathrm{G})$ in strong $\mathrm{LD}\left(\mathrm{r}^{2}=0.81\right)$ with the former was used as a proxy SNP to validate the locus. Similarly, the proxy SNP of rs 2667773 (A/G) is rs2667768 (C/A) ( $\left.\mathrm{r}^{2}=0.87\right)$. The proxy SNP of rs56113850 (T/C) is rs1496402 (T/A) $\left(\mathrm{r}^{2}=0.70\right)$. 
Table 2. The causal associations between coffee consumption and human health outcomes based on the TSMR analysis.

\begin{tabular}{|c|c|c|c|c|c|c|c|c|}
\hline Outcome category & Outcome & Nsnp & BETA & SE & $\mathrm{P}$ & FDR & Heterogeneity & Pleiotropy \\
\hline \multirow[t]{5}{*}{ lipid } & Serum total cholesterol || id:933 & 41 & 0.133 & 0.041 & $1.27 \times 10^{-3}$ & $1.86 \times 10^{-2}$ & 0.261 & 0.599 \\
\hline & Serum total triglycerides $\|$ id:934 & 40 & 0.154 & 0.043 & $3.75 \times 10^{-4}$ & $9.53 \times 10^{-3}$ & 0.155 & 0.628 \\
\hline & Total cholesterol in LDL $\|$ id:895 & 41 & 0.191 & 0.042 & $4.49 \times 10^{-6}$ & $9.34 \times 10^{-4}$ & 0.233 & 0.939 \\
\hline & Total cholesterol in HDL || id:864 & 42 & -0.128 & 0.039 & $8.76 \times 10^{-4}$ & $1.45 \times 10^{-2}$ & 0.642 & 0.746 \\
\hline & Apolipoprotein B || id:843 & 40 & 0.233 & 0.043 & $4.38 \times 10^{-8}$ & $4.54 \times 10^{-5}$ & 0.247 & 0.635 \\
\hline \multirow[t]{5}{*}{ Anthropometric } & Overweight || id:93 & 27 & 0.124 & 0.047 & $8.87 \times 10^{-3}$ & $7.75 \times 10^{-2}$ & 0.118 & 0.889 \\
\hline & Obesity class $1 \|$ id:90 & 27 & 0.195 & 0.069 & $4.45 \times 10^{-3}$ & $4.43 \times 10^{-2}$ & 0.085 & 0.972 \\
\hline & Waist circumference $\|$ id:61 & 27 & 0.062 & 0.019 & $9.21 \times 10^{-4}$ & $1.45 \times 10^{-2}$ & 0.278 & 0.569 \\
\hline & Waist-to-hip ratio $\|$ id:74 & 27 & 0.090 & 0.024 & $2.18 \times 10^{-4}$ & $7.10 \times 10^{-3}$ & 0.192 & 0.861 \\
\hline & Body mass index || id:785 & 26 & 0.080 & 0.024 & $7.19 \times 10^{-4}$ & $1.29 \times 10^{-2}$ & 0.154 & 0.919 \\
\hline \multirow[t]{3}{*}{ Diabetes } & Type 2 diabetes $\|$ id:25 & 2 & 1.154 & 0.391 & $3.18 \times 10^{-3}$ & $3.45 \times 10^{-2}$ & 0.317 & NA \\
\hline & AUCins || id:760 & 28 & -0.249 & 0.111 & $2.48 \times 10^{-2}$ & $1.47 \times 10^{-1}$ & 0.309 & 0.023 \\
\hline & Corrected insulin response $\|$ id:761 & 27 & -0.206 & 0.096 & $3.21 \times 10^{-2}$ & $1.69 \times 10^{-1}$ & 0.650 & 0.207 \\
\hline \multirow[t]{2}{*}{ Cancer } & Endometrioid ovarian cancer $\|$ id:1125 & 43 & 0.349 & 0.112 & $1.84 \times 10^{-3}$ & $2.37 \times 10^{-2}$ & 0.736 & 0.913 \\
\hline & Serous ovarian cancer: low grade and low malignant potential $\|$ id:1229 & 43 & -0.331 & 0.129 & $1.05 \times 10^{-2}$ & $8.66 \times 10^{-2}$ & 0.074 & 0.787 \\
\hline
\end{tabular}

Footnotes: The outcomes causally associated with coffee consumption in our phenotype-wide TSMR analysis, which were categorized using the definitions in MR-Base, with a slight modification by merging the insulinemic outcomes into the "diabetes" category. The Outcome is the descriptive phenotype with a unique id assigned by MR-Base; Nsnp: the number of IVs used in TSMR; BETA: the causal effect of coffee consumption on outcome; SE: the standard error; P: the p-value of TSMR analysis; FDR: false discovery rate;

Heterogeneity: the p-value of Cochran's Q value; Pleiotropy: the p-value of MR-Egger intercept. 


\begin{tabular}{|c|c|c|c|c|c|}
\hline Outcome category & Outcome & $\mathrm{N}$ (case | control) & BETA & SE & $\mathrm{P}$ \\
\hline Age & Age & 193674 & 7.407 & 6.264 & $2.37 \times 10^{-1}$ \\
\hline Sex & Sex & 193674 & 0.053 & 0.393 & $8.92 \times 10^{-1}$ \\
\hline \multirow[t]{5}{*}{ Lipids } & Cholesterol & 184858 & 3.333 & 0.885 & $1.65 \times 10^{-4}$ \\
\hline & LDL & 184540 & 3.013 & 0.674 & $7.76 \times 10^{-6}$ \\
\hline & Apolipoprotein B & 183961 & 0.788 & 0.180 & $1.24 \times 10^{-5}$ \\
\hline & HDL & 169307 & -0.862 & 0.317 & $6.56 \times 10^{-3}$ \\
\hline & Apolipoprotein A & 168330 & -0.412 & 0.220 & $6.08 \times 10^{-2}$ \\
\hline \multirow[t]{4}{*}{ Anthropometric } & Waist circumference & 193635 & 50.085 & 8.012 & $4.08 \times 10^{-10}$ \\
\hline & Hip circumference & 193634 & 31.293 & 5.416 & $7.56 \times 10^{-9}$ \\
\hline & Body mass index & 193674 & 21.551 & 2.733 & $3.18 \times 10^{-15}$ \\
\hline & Weight & 193674 & 52.653 & 9.465 & $2.66 \times 10^{-8}$ \\
\hline \multirow[t]{3}{*}{ Diabetes } & Glucose & 169192 & 0.411 & 0.603 & $4.95 \times 10^{-1}$ \\
\hline & Glycated haemoglobin (HbA1c) & 184763 & 19.021 & 4.088 & $3.28 \times 10^{-6}$ \\
\hline & Diabetes & $9367 \mid 183926$ & 0.334 & 0.090 & $2.00 \times 10^{-4}$ \\
\hline Cancer & Ovarian cancer & $885 \mid 101366$ & -0.195 & 0.098 & $4.80 \times 10^{-2}$ \\
\hline
\end{tabular}

Footnotes: Outcome categories based on the definitions in MR-Base. Similarly, we also classified glycemic outcomes into the

“diabetes" category. N, the number of participants used in OSMR; BETA, the regression coefficient of coffee consumption PRS; SE,

the standard error of BETA; P: the p-value of OSMR analysis. 